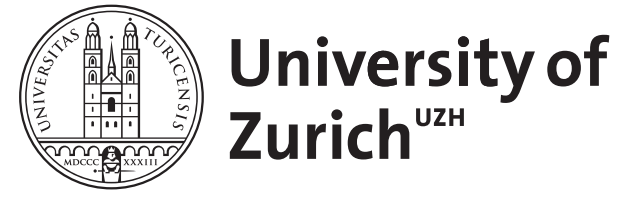

\title{
Food and Food Production
}

\author{
Altmann, Peter
}

DOI: https://doi.org/10.1093/OBO/9780195393361-0022

Posted at the Zurich Open Repository and Archive, University of Zurich

ZORA URL: https://doi.org/10.5167/uzh-54222

Scientific Publication in Electronic Form

Originally published at:

Altmann, Peter (2012). Food and Food Production. New York: Oxford University Press.

DOI: https://doi.org/10.1093/OBO/9780195393361-0022 


\section{OXFORD BIBLIOGRAPHIES IN BIBLICAL STUDIES} "FOOD AND FOOD PRODUCTION" by Peter Altmann

(C) Oxford University Press, Inc.

Not for distribution. For permissions, please email OxfordBibliographies@oup.com. 


\section{FOOD AND FOOD PRODUCTION}

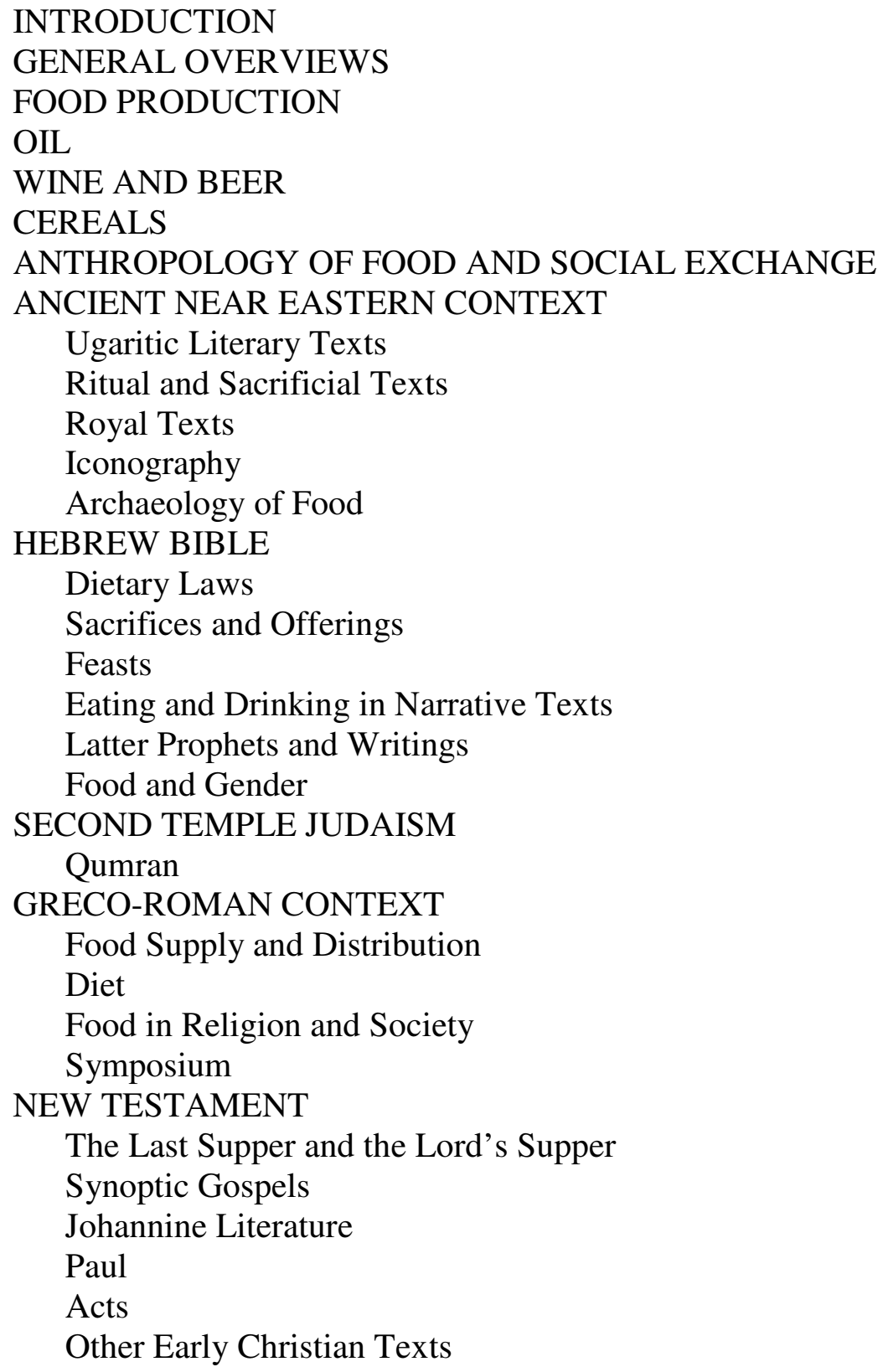

\section{Introduction}

Food and food production form the settings for a plethora of Old and New Testament texts as well as the metaphorical material used by texts for a variety of purposes. The basic "Mediterranean diet" of olive oil, grains, and grapes and their production are the everyday staples, often supplemented by festive meals. Meals display important theological, anthropological, and political events, highlighting both the materiality of the biblical discourses and the use of material images for broader arguments. Uses of food in the Hebrew Bible are deeply influenced by the political and religious traditions of the 
ancient Near East, such as Assyria, Egypt, Babylon, and Ugarit. New Testament texts interact with both the Greco-Roman and earlier Israelite traditions.

\section{General Overviews}

Claassens 2006 and Jenks 1992 give short overviews of the directions of scholarship in biblical studies on food. In general the discussion of food and meals in the past decades has moved from simply addressing questions of what people ate to also including the anthropological dynamics surrounding eating and the metaphorical/symbolic meanings of food. For the "hard facts" on food and archaeology, see MacDonald 2008. Brothwell and Brothwell 1998 is from the perspective of a generalist. Dalman 1964 provides extensive detail from personal observation. Dalby 2003 is a good starting point, especially for further bibliography, while the strength of Wilkins, et al. 1995 is that it combines perspectives from a variety of experts in each subfield. Kaufman 2006 provides essaylength treatments, thus a bit more depth than the encyclopedia works.

Brothwell, Don R., and Patricia Brothwell. Food in Antiquity: A Survey of the Diet of Early Peoples. Baltimore: Johns Hopkins University Press, 1998.

Reprint with afterword of an older (1969) edition, but still useful survey of food production and consumption practices throughout the ancient world. Most helpful for comparisons with other ancient cultures.

Claassens, L. Juliana M. "Food.” In New Interpreters Dictionary of the Bible. Vol. 2. Edited by Katharine D. Sakenfeld, 472-476. Nashville: Abingdon, 2006.

Provides concise overview of diet and dietary concerns, role of food in the cult, use of food imagery, table fellowship, and gender questions with regard to food.

Dalby, Andrew. Food in the Ancient World, from A to Z. London: Routledge, 2003.

Encyclopedia entries with good introductory bibliographies.

Dalman, Gustaf Hermann. Arbeit und Sitte in Palästina. Deutsches evangelisches Institut für Altertumswissenschaft des Heiligen Landes zu Jerusalem, Schriften 3/1-2.

Hildesheim, Germany: Georg Olms, 1964.

Foundational multivolume study. Based on years of observation of rural communities in the Levant in the early 20th century. Helpful for entire biblical (and Mishnaic) period. Originally published 1928-1942 (Gütersloh, Germany: Bertelsmann).

Jenks, Alan W. "Eating and Drinking in the Old Testament." Anchor Bible Dictionary. Vol. 2. Edited by David Noel Freedman, 250-254. New York: Doubleday, 1992. 
From a generation of scholarship previous to that of Claassens 2006, and therefore especially helpful in illustrating the direction scholarship has taken.

Kaufman, Cathy K. Cooking in Ancient Civilizations. Westport, CT: Greenwood, 2006.

Offers colorful portraits across various ancient Near Eastern (and other) cultures to help imagine the situation.

MacDonald, Nathan. What Did the Israelites Eat? Diet in Biblical Times. Grand Rapids, MI: Eerdmans, 2008.

Draws together data from diverse ancient textual sources, recent archaeological excavations, and comparative anthropological studies to construct a composite understanding of diet. More focused on Old Testament/Hebrew Bible period, but also very useful for New Testament.

Wilkins, John, F. D. Harvey, and Michael J. Dobson, eds. Food in Antiquity. Exeter, UK: University of Exeter Press, 1995.

Made up of short articles from experts from different fields. Focused mostly on the Greco-Roman world.

\section{Food Production}

The two books by Borowski (Borowski 1987, Borowski 1998) are short monographs that give more detail than the citations in General Overviews but are still popular introductions. Schmitt 1994 is best used as a reference work for individual biblical texts, though it also provides some helpful anthropological insights for methodology. Curtis 2001 gives a well-structured introduction to the cultures and geographic regions that composed the biblical worlds.

Borowski, Oded. Agriculture in Iron Age Israel. Winona Lake, IN: Eisenbrauns, 1987.

Good overview of food production practices used throughout the biblical periods.

Borowski, Oded. Every Living Thing: Daily Use of Animals in Ancient Israel. Walnut Creek, CA: Altamira, 1998.

Helpful popular introduction in the uses and views toward various animals during the Old Testament period. Considers both archaeological and biblical evidence. Considers agricultural, cultic, and other uses.

Curtis, Robert I. Ancient Food Technology. Technology and Change in History 5. Leiden, The Netherlands: E. J. Brill, 2001. 
Handbook of techniques and technologies of agriculture in the ancient Mediterranean and Near East, split into the prehistoric period, the historical period of Egypt and the ancient Near East, and the Greco-Roman period. Clear overview with very helpful bibliographies. Considers literary, archaeological, epigraphic, and art historical sources.

Schmitt, Eleanore. Das Essen in der Bibel: Literaturethnologische Aspekte des Alltäglichen. Studien zur Kulturanthropologie 2. Münster, Germany: Lit, 1994.

One of the first studies of food in the Old Testament/Hebrew Bible. Attempts to analyze food practices in the culture behind the text, often assuming that the culture is singular.

\section{Oil}

Amouretti and Brun 1993 provides detailed accounts on the wider geographical region, while Heltzer and Eitam 1987 contains detailed studies on olive oil production from an archaeological perspective based solely in the Levant. See also Decker 2001 and Frankel 1999 (both cited under Wine and Beer) for information on archaeological installations for oil production. Foxhall 2007 is more interdisciplinary, considering oil as an integrated part of society.

Amouretti, Marie-Claire, and Jean-Pierre Brun, eds. La production du vin et de l'huile en Méditerranée: Oil and wine production in the Mediterranean Area. Bulletin de correspondence hellénique, Supplément 26. Athens, Greece: Ecole française d'Athènes, 1993.

Essays in French and English addressing the entire Mediterranean region from pharaonic Egypt and the Iron Age Levant to medieval Europe. Most helpful for interpretations of archaeological finds as they relate to wine and oil.

Foxhall, Lin. Olive Cultivation in Ancient Greece: Seeking the Ancient Economy. Oxford: Oxford University Press, 2007.

This study considers the 6th to the 3rd centuries bce and gives an entrée to the social values, agricultural practice, technology, and economics of olive production. Considers oil production as a part of these various systems. Helpful for bringing together various methodological and societal threads that are often separated.

Heltzer, Michael, and David Eitam, eds. Olive Oil in Antiquity: Israel and Neighboring Countries from Neolithic to Early Arab Period. Haifa, Israel: University of Haifa, 1987.

Collected volume of essays addressing specific issues concerning the archaeology of oil presses and the distribution of oil. Helpful for understanding how archaeology takes the raw data and builds hypothesis concerning historical 
developments (e.g., with regard to Assyrian involvement in the oil consumption or trade).

\section{Wine and Beer}

Dayagi-Mendels 1999 focuses on the entire Mediterranean region and developments from earliest times to the Greco-Roman period. Albright 1981 offers introductory studies into the broader issues of production and use, while Dubach 2009 focuses on single issues with straightforward methodologies, thus providing a wealth of information. Walsh 2000 gives more epigraphic background and relates it primarily to a single biblical text. Decker 2001 is more applicable for the New Testament and early Christian context. Frankel 1999 is the most detailed treatment of the archaeological data.

Albright, Jimmy Lee. "Wine in the Biblical World: Its Economic, Social, and Religious Implications for New Testament Interpretation.” PhD diss., Southwestern Baptist Theological Seminary, Fort Worth, TX, 1981.

Systematic, if somewhat dated, introduction into the archaeological and broader issues surrounding especially wine production, but also some comments on use in Antiquity. Compare also with Walsh 2000 and Dubach 2009.

Dayagi-Mendels, Michal. Drink and Be Merry: Wine and Beer in Ancient Times. Jerusalem: The Israel Museum, 1999.

Popular overview of the long-term development. Complete with numerous illustrations.

Decker, Michael. "Food for an Empire: Wine and Oil Production in North Syria." In Economy and Exchange in the East Mediterranean during Late Antiquity. Proceedings of a Conference at Somerville College, Oxford, 29th May, 1999. Edited by Sean Kingsley and Michael Decker, 69-86. Oxford: Oxbow, 2001.

Explores the provision of the Eastern Roman Empire by Northern Syria in the 4th century bce and later. While addressing a post-biblical period, the concerns and argumentation display the factors at play in feeding cities and empires (especially transportation) in Antiquity.

Dubach, Manuel. Trunkenheit im Alten Testament: Begrifflichkeit-Zeugnisse-Wertung. Beiträge zur Wissenschaft vom Alten und Neuen Testament 184. Stuttgart: Kohlhammer, 2009.

Discussion of all the Hebrew words used for drunkenness and how drinking and drunkenness is depicted. Good philological discussions and helpful for an overview. Can be used as a reference guide for particular texts. 
Frankel, Rafael. Wine and Oil Production in Antiquity in Israel and Other Mediterranean Countries. JSOT/ASOR Monographs 10. Sheffield, UK: Sheffield Academic Press, 1999.

Thorough monograph detailing the archaeological data of wine and oil production installations. Focuses on regional diversity. Shows how the process changed from the Bronze Age to the Hellenistic period, mostly in the Levant. Some brief interactions with epigraphic, biblical, and Talmudic evidence as well.

Walsh, Carey Ellen. The Fruit of the Vine: Viticulture in Ancient Israel. Harvard Semitic Monographs 60. Winona Lake, IN: Eisenbrauns, 2000.

Investigates viticulture in the Old Testament and ancient written sources. Thorough discussion of the sociological background of the theme of grape growing and wine consumption, especially of the 1 Kings 21 story of Naboth's vineyard.

\section{Cereals}

Jardé 1979 is a thorough foundation for modern scholarship, while Garnsey 1998 outlines recent developments through the work of one leading voice. Gallant 1991 gives an interdisciplinary analysis of the basic question of survival. Garnsey and Morris 2004 considers grain procurement in relation to the changes in political structures.

Gallant, Thomas W. Risk and Survival in Ancient Greece: Reconstructing the Rural Domestic Economy. Stanford, CA: Stanford University Press, 1991.

Considers survival strategies for food production and procurement in rural ancient Greece in light of difficulties resulting from climate and human disasters. Uses cross-cultural comparisons and computer simulations to construct his argument. Seen as a complement to Garnsey 1998. Helpful for the incorporation of both technical and social responses by ancient Greek families.

Garnsey, Peter. Cities, Peasants, and Food in Classical Antiquity: Essays in Social and Economic History. Edited by Walter Scheidel. Cambridge, UK, and New York: Cambridge University Press, 1998.

The third section of this book of collected essays brings together earlier articles by a leading, established scholar in the field on the social symbolism of food (beans) and material aspects (feeding Athens, nutrition in Rome, and famine). Helpful for tracing the development of scholarly thought. Each essay also includes an addendum by the editor, explaining the development of scholarship since their initial appearance.

Garnsey, Peter, and Ian Morris. "Risk and the Polis: The Evolution of Institutionalised Responses to Food Supply Problems in the Ancient Greek State." In Bad Year Economics: Cultural Responses to Risk and Uncertainty. Edited by P. Halstead and J. 
O'Shea, 98-105. New Directions in Archaeology. Cambridge, UK, and New York: Cambridge University Press, 2004.

This brief article attempts to tie the development of various state structures (polis) as well as colonization in archaic Greece, developed to counteract the risk of famine that resulted from frequent crop failure. Also gives an overview of the ways classical Greek cities managed food crises through legal actions and euergetism.

Jardé, Auguste. Les céréales dans l'antiquité grecque: La production. Bibliothèque des écoles francaises d'Athènes et de Rome 130. Paris: E. de Boccard, 1979.

Early investigation (original publication 1925) of pre-Hellenistic Greek agricultural practices as well as some basic economic factors related to grain production. Forms the basis for all later scholarship.

\section{Anthropology of Food and Social Exchange}

Recent scholarship on food has expanded its focus to include the social and cultural dynamics associated especially with communal consumption. Biblical interpretations have received impetus here from similar currents in anthropology and sociology. Dietler and Hayden 2001 provides an entrée into these discussions across historical disciplines, while Sutton 2001 is an insightful treatment of a modern context that is suggestive for the biblical material. Messer 1984 offers a great summary of research up to the date of the publication. The insights presented here are found in many of the works directed to the biblical material found below (but see especially Feasts, Food in Religion and Society, and Symposium).

Dietler, Michael, and Brian Hayden, eds. Feasts: Archaeological and Ethnographic Perspectives on Food, Politics, and Power. Smithsonian Series in Archaeological Inquiry. Washington, DC: Smithsonian Institution Press, 2001.

The first two essays in particular detail the different ways that feasts can be employed within particular cultural settings. Addresses the classification of feasts and their relationships to social power and communal action. The remainder of the essays investigate individual historical contexts.

Messer, Ellen. "Anthropological Perspectives on Diet." Annual Review of Anthropology 13 (1984): 205-249.

Bibliographical summary of research on food studies, giving the range of potential important factors for understanding attitudes toward foods in particular cultures.

Sutton, David P. Remembrance of Repasts: An Anthropology of Food and Memory. Oxford: Berg, 2001. 
Considers the role of food consumption in social contexts for the formation of communal and individual identity. Though it addresses modern Greek culture, the theoretical underpinnings are important transculturally.

\section{Ancient Near Eastern Context}

Understanding Old Testament/Hebrew Bible mention of food and drink is enriched when augmented by some comparison with the practices of the surrounding cultures. Bottéro 2004 and Ikram 1995 provide specific overviews from the imperial powers dominating ancient Israel's world. Further examples are provided in these subsections: Ugaritic Literary Texts, Ritual and Sacrificial Texts, Royal Texts, Iconography, Food Production, and Archaeology of Food.

Bottéro, Jean. The Oldest Cuisine in the World: Cooking in Mesopotamia. Translated by Teresa Lavender Fagan. Chicago: University of Chicago Press, 2004.

English translation of Plus vieille cuisine du monde, published in 2002. Readable, engaging overview of both the general cuisine and some specific recipes and the basic cultic settings for feasts. Also considers differences in elite versus common diets. Great introduction.

Ikram, Salima. Choice Cuts: Meat Production in Ancient Egypt. Orientalia Lovaniensia Analecta 69. Leuven, Belgium: Peeters, 1995.

Very detailed discussion of textual, archaeological, and iconographic sources in order to discern how meat came to the table in ancient Egypt and its role in the society.

Wright, Jacob L. "Commensal Politics in Ancient Western Asia: The Background to Nehemiah's Feasting." Zeitschrift für die alttestamentliche Wissenschaft 122.2-3 (2010): 212-231, 333-352.

Concise summary of a number of anthropological, iconographic, and textual concerns for interpreting biblical texts. Includes a number of illustrations with insightful commentary.

\section{Ugaritic Literary Texts}

These three works provide detailed expositions of specific narratives. Lloyd 1990 offers an overview of the texts involved. Belnap 2007 and Wright 2001 integrate anthropological and philological methodologies. These Ugaritic narratives are essential for understanding many Hebrew Bible texts, including those concerned with divine or royal banqueting (see Royal Texts). 
Belnap, Daniel. "Fillets of Fatling and Goblets of Gold: The Use of Meal Events in the Ritual Imagery of the Ugaritic Mythological and Epic Texts." PhD diss., University of Chicago, 2007.

Uses recent anthropological and detailed philological approaches to interpret most Ugaritic narrative texts and also applies the analysis to several biblical texts.

Good example of interdisciplinary methodology.

Lloyd, J. B. "The Banquet Theme in Ugaritic Narrative." Ugarit-Forschungen 22 (1990): 169-193.

Compares the most important Ugaritic narrative banquets as well as Exodus 24 and Jeremiah 51 and concludes that there is a typical order of events that structures the meal, which carries over from Ugarit into these biblical texts.

Wright, David P. Ritual in Narrative: The Dynamics of Feasting, Mourning, and Retaliation Rites in the Ugaritic Tale of Aqhat. Winona Lake, IN: Eisenbrauns, 2001.

Clear, methodologically astute presentation of the most important feasts in the Ugaritic Aqhat narrative. Considers literary depictions of rituals, including feasting, in terms of their literary value, discounting their necessary historicity. Helpful for understanding rituals in biblical narratives.

\section{Ritual and Sacrificial Texts}

Understanding the biblical sacrificial systems and the roles played in them by food and drink can be done by comparison and contrast with those of Mesopotamia in Abusch 2002, Lambert 1993, and Scurlock 2002. Clemens 1999 is helpful for close analysis of the Biblical Hebrew terminology for sacrifice, given that Ugarit is the closest geographic and philological neighbor for which extensive data are available.

Abusch, Tzvi. "Sacrifice in Mesopotamia." In Sacrifice in Religious Experience. Edited by Albert I. Baumgarten, 39-48. Leiden, The Netherlands: E. J. Brill, 2002.

Contrasts the understanding of sacrifice in Mesopotamia with that of the Levant and the Old Testament, concluding that in Mesopotamia the presentation of the meal was of central importance.

Clemens, David M. “A Study of the Sacrificial Terminology at Ugarit: A Collection and Analysis of the Ugaritic and Akkadian Textual Data." Vol. 1. PhD diss., University of Chicago, 1999.

Methodically and thoroughly investigates each occurrence in the Ugaritic corpus to determine the meaning of each sacrificial term. Useful as a lexical tool. 
Lambert, Wilfred G. "Donations of Food and Drink to the Gods in Ancient Mesopotamia." In Ritual and Sacrifice in the Ancient Near East: Proceedings of the International Conference Organized by the Katholieke Universiteit Leuven from the 17th to the 20th of April 1991. Edited by J. Quaegebeur, 191-201. Orientalia Lovaniensia Analecta 55. Leuven, Belgium: Peeters, 1993.

Like Abusch 2002, Lambert concludes that the closest analogue to sacrifice in Mesopotamia was the presentation of meals to the gods. Notes that in Mesopotamian myth, humans were created to feed the gods.

Scurlock, Joann. "Animal Sacrifice in Ancient Mesopotamian Religion.” In A History of the Animal World in the Ancient Near East. Edited by Billie Jean Collins, 389-404. Handbuch der Orientalistik 64. Leiden, The Netherlands: E. J. Brill, 2002.

Outlines the general frequency of animal sacrifice as part of the divine meal in Mesopotamia, including typical cultural expectations, since regular servings of meat were befitting for royalty and divinity.

\section{Royal Texts}

The king's role as host of the banquet is an often-used motif displaying his power throughout the ancient Near East and beyond. Finet 1992 presents the most detailed description; Masetti-Rouault 2002 journals the historical development in Assyria. Parpola 2004 addresses the commonalities between Neo-Assyrian and the later Persian practices. For the early Mari (ancient Syria) practices, see Sasson 2004.

Finet, Andre. "Le Banquet de Kalah offert par le Roi d'Assyrie Ašurnasirpal II (883859)." In Banquets d'Orient. Edited by Rika Gyselen, 31-44. Res Orientales IV. Buressur-Yvette, France: Groupe pour L'Étude de la Civilisation du Moyen-Orient, 1992.

Basic discussion and translation of the Akkadian of this key banquet that dedicated a city. Important for understanding royal feasts in the Hebrew Bible and for its list of included foods and the inclusion of a huge crowd; both motifs are also found in biblical texts.

Masetti-Rouault, Maria Grazia. "Le roi, la fête et le sacrifice dans les inscriptions Royales assyriennes jusqu'au VIIIe siècle Av. J.-C.” In Fêtes et Festivités, 67-95. By Association Kubaba. Cahiers Kubaba 4:1. Paris: L'Harmattan, 2002.

Helpful for its tracing of the role that the royal feast plays in Neo-Assyrian inscriptions up to the 8th century bce. Available for purchase online.

Parpola, Simo. "The Leftovers of God and King: On the Distribution of Meat at the Assyrian and Achaemenid Imperial Courts." In Food and Identity in the Ancient World. Edited by Christiano Grottanelli and Lucio Milano, 281-312. History of the Ancient Near East Studies 9. Padua, Italy: Sargon, 2004. 
Argues that the tradition of royal banquets remained stable from Neo-Assyria through to Xenophon's portrayals of Persian imperial banquets, based on letters from the Neo-Assyrian period detailing the importance of who received leftovers from temple sacrifices.

Sasson, Jack M. "The King's Table: Food and Fealty in Old Babylonian Mari." In Food and Identity in the Ancient World. Edited by Christiano Grottanelli and Lucio Milano, 179-215. History of the Ancient Near East Studies 9. Padua, Italy: Sargon, 2004.

Investigates texts from Mari that detail where meals were cooked, types of dishes, and guests. Concludes that meals were very significant for diplomacy.

\section{Iconography}

The iconographic depictions of banquets, agricultural work, and sacrifices augment and give their own views of ancient food culture. Pritchard 1969 is the most accessible collection. Barnett 1985 presents arguably the most well-known depiction, while Struble and Hermann 2009 is the most recent. Collon 1992 and Pinnock 1994 detail the development across cultures and historical periods.

Barnett, Richard D. “Assurbanipal’s Feast.” Eretz Israel 18 (1985): 1-6.

Argues that this well-known Assyrian iconographic portrayal reveals marzeah themes with the ruler on couch and a woman eating, so perhaps it shows Greek influence.

Collon, Dominique. "Banquets in the Art of the Ancient Near East." In Banquets D’Orient. Edited by Rika Gyselen, 23-30. Res Orientales IV. Bures-sur-Yvette, France: Groupe pour L'Étude de la Civilisation du Moyen-Orient, 1992.

Clear overview of banquet iconography from earliest times to the Neo-Babylonian period.

Pinnock, Frances. 'Considerations on the 'Banquet Theme' in the Figurative Art of Mesopotamia and Syria." In Drinking in Ancient Societies: History and Culture of Drinks in the Ancient Near East. Edited by Lucio Milano, 15-26. History of Ancient Near East Studies 6. Padua, Italy: Sargon, 1994.

Looks at the development of human banquets from the Akkadian to Neo-Assyrian periods. Shows the ubiquity of the portrayals and evaluates continuity and different uses of the motif.

Pritchard, James B. The Ancient Near East in Pictures Relating to the Old Testament. 2d ed. Princeton, NJ: Princeton University Press, 1969. 
Essential starting point for photographs and representations of iconography. Many depictions of meals, food products, and food production.

Struble, Eudora J., and Virginia Rimmer Hermann. “An Eternal Feast at Sam'al: The New Iron Age Mortuary Stele from Zincirli in Context." Bulletin of the American Schools of Oriental Research 356 (2009): 15-49.

Thorough analysis of very recent funeral iconographic portrayal. Shows current scholarly approaches to understanding funeral meals.

\section{Archaeology of Food}

The entries here vary from broad overviews to detailed analysis of individual sites. Schmandt-Besserat 2001 is helpful for the Mesopotamian background for the Old Testament. Hellwing, et al. 1993 provides an example of how animal bone data are analyzed, while Payne 1973 discusses the data on a theoretical basis. See Hesse and Wapnish 1997 for a discussion of the correlation between dietary laws and ethnicity, and see Horwitz 1986-1987 on sacrifice. Wapnish 1993 gives an example of how bone finds can be related to particular historical events.

Hellwing, Shlomo, Moshe Sadeh, and Vered Kishon. "Faunal Remains." In Shiloh: The Archaeology of a Biblical Site. Edited by Israel Finkelstein, 309-350. Tel Aviv: Tel Aviv University, 1993.

Example of how animal remains are collected and analyzed at an archaeological site. Gives insight into the foundation of how archaeological arguments are constructed for understanding food production and consumption (for similar essays on other sites, see MacDonald 2008 under Eating and Drinking in Narrative Texts).

Hesse, Brian, and Paula Wapnish. "Can Pig Remains Be Used for Ethnic Diagnosis in the Ancient Near East?" In The Archaeology of Israel: Constructing the Past, Interpreting the Present. Edited by Neil Asher Silberman and David Small, 238-271. Journal for the Study of the Old Testament Supplement 237. Sheffield, UK: Sheffield Academic Press, 1997.

Attempts to relate the dietary taboo on pig in the Old Testament to the archaeological provenance of pig bones (which were found in Philistia, but not in the Israelite highlands) to identify the early Israelites. Detailed and debated conclusions.

Horwitz, Loira Kolska. "Faunal Remains from Mount Ebal.” Tel Aviv 13-14 (19861987): 173-187.

Discussion of one of the rare archaeological sites for which sacrifice is also mentioned in the Hebrew Bible. 
Payne, Sabastian. "Kill-Off Patterns in Sheep and Goats: The Mandibles from Aşvan Kale." Anatolian Studies 23 (1973): 281-303.

Provides a necessary theoretical basis for understanding how the faunal remains (animal bones) found at archaeological sites can be used to project the use of these animals in the society.

Schmandt-Besserat, Denise. "Feasting in the Ancient Near East." In Feasts:

Archaeological and Ethnographic Perspectives on Food, Politics, and Power. Edited by Michael Dietler and Brian Hayden, 391-403. Washington, DC: Smithsonian Institution Press, 2001.

Brief overview of iconography and the sociopolitical setting of feasts.

Wapnish, Paula. "Archaeozoology: The Integration of Faunal Data with Biblical Archaeology." In Biblical Archaeology Today, 1990: Proceedings of the Second International Congress on Biblical Archaeology. Edited by A. Biran and J. Aviram, 426442. Jerusalem: Israel Exploration Society, 1993.

Takes analyses of animal bones found in ancient Israel and Palestine and attempts to relate them to the historical events of the period. Especially interesting is the consideration of the Assyrian period of the 8th-7th centuries bce.

\section{Hebrew Bible}

Food and food production in the Hebrew Bible/Old Testament serve as one of the most ubiquitous and overlooked topics. Biblical interpretation has tended to focus on theological, philosophical, and intellectual ideas, thereby relegating material issues, such as meals and food, to the sidelines. The overall ethical relationships among food, agriculture, power, culture, and theology are on display in Davis 2009 and Reed 1997. Davis's argument is quite detailed in its attempt to bring together different eras, but for this reason it is also suggestive for further thinking. Stone 2005 addresses one of the highly pertinent questions from current culture. The essays in Geiger, et al. 2009 provide numerous approaches in current German-speaking scholarship. Beyond these treatments, the questions of dietary laws, food metaphors, sacrifice, feasts, and food in specific texts are treated in separate subsections.

Davis, Ellen F. Scripture, Culture, and Agriculture: An Agrarian Reading of the Bible. Cambridge, UK: Cambridge University Press, 2009.

Intertwines analysis of Hebrew Bible texts, data from recent governmental and international surveys, and agrarian philosophical ideals to argue that the Old Testament offers ethical reflection pertinent for the modern global production of food. 
Geiger, Michaele, Christl M. Maier, and Uta Schmidt, eds. Essen und Trinken in der Bibel: Ein literarisches Festmahl für Rainer Kessler zum 65. Geburtstag. Gütersloh, Germany: Gütersloher Verlagshaus, 2009.

Mainly Old Testament text discussions (with three essays on New Testament topics) addressing questions of commensality, ethics and hunger, food metaphors, and especially literary-theological perspectives on the food-and-drink portrayals in the texts.

Reed, Stephen. "Meat Eating and the Hebrew Bible." In Problems in Biblical Theology: Essays in Honor of Rolf Knierim. Edited by Henry T. C. Sun and Keith L. Eades, 281294. Grand Rapids, MI: Eerdmans, 1997.

Good for theological reflection on the diverse Old Testament perspectives on meat consumption. Short overview.

Stone, Ken. Practicing Safer Texts: Food, Sex and Bible in Queer Perspective. London: T\&T Clark, 2005.

Reads a variety of Hebrew Bible texts that connect food and sex, attempting both to examine what the texts say and to determine how they should be ethically received or rejected.

\section{Dietary Laws}

The question of the origins and purpose of the dietary laws in Leviticus 11 and Deuteronomy 14, which gave rise to the practices in modern Judaism, has spawned many opinions. Soler 1979 and Douglas 1966 offer structural interpretations, while Harris 1997 is an alternative materialist approach. Milgrom 1963 builds on and refines the structuralist reading and is written by a leading Leviticus scholar. Alter 1979 offers a more popular but still well-reasoned and informed argument. Houston 2003 nuances earlier proposals, while the author's earlier work (Houston 1993) distinctively relates the dietary laws to the development of monotheism.

Alter, Robert. “A New Theory of Kashrut.” Commentary 68.3 (1979): 46-52.

By a well-respected literary critic and biblical interpreter. Critiques earlier views in Soler 1979 and Douglas 1966.

Douglas, Mary. Purity and Danger: An Analysis of the Concepts of Pollution and Taboo. London: Routledge \& Kegan Paul, 1966.

Classic interpretation of the dietary laws in Leviticus 11, arguing that the basic concept underlying particular animals' exclusion from the table is that they have characteristics that make it difficult to fit them easily into one particular category. 
Harris, Marvin. "The Abominable Pig." In Food and Culture: A Reader. Edited by Carole Counihan and Penny van Esterik, 67-79. New York: Routledge, 1997.

Reprinted from pages 67-81 in Good to Eat: Riddles of Food and Culture (New York: Simon \& Schuster, 1985). Contrary to Douglas, this text interprets the meaning of dietary laws as arising from material food-production questions.

Houston, Walter J. Purity and Monotheism: Clean and Unclean Animals in Biblical Law. Journal for the Study of the Old Testament Supplement 140. Sheffield, UK: Sheffield Academic Press, 1993.

Good analysis of the difference between the cultural materialism of Harris 1997 and the structuralism of Douglas 1966 and Milgrom 1963. Well grounded in the archaeology of comparative cultures of ancient Israel and surrounding areas. Works diachronically to develop thesis and continues into the early Christian period.

Houston, Walter J. "Towards an Integrated Reading of the Dietary Laws of Leviticus." In The Book of Leviticus: Composition and Reception. Edited by Rolf Rendtorff, Robert A. Kugler, and Sarah Smith Bartel, 142-161. Supplements to Vetus Testamentum 93. Leiden, The Netherlands: E. J. Brill, 2003.

Clear overview of the history of scholarship, including Philo, Douglas, Milgrom, and Klawans, also offering an entry into the project of Houston's monograph Purity and Monotheism.

Milgrom, Jacob. "Biblical Diet Laws as Ethical System.” Interpretation 17 (1963): 288301.

Builds on and refines Douglas's structural analysis of Leviticus 11. Significant development is the argument that the underlying logic of the dietary laws is to value life, so carnivores are viewed as inedible.

Soler, Jean. "The Semiotics of Food in the Bible." In Food and Drink in History: Selections from the Annales Economies, Societes, Civilisations. Vol. 5. Edited by R. Forster and O. Ranum, 126-138. Translated by E. Forster and P. M. Ranum. Baltimore: Johns Hopkins University, 1979.

Structuralist interpretation similar to Douglas 1966. Easily accessible, clearly written.

\section{Sacrifices and Offerings}

One of the main contexts for festive consumption, especially meat consumption, took place in conjunction with sacrificial offerings. Anderson 1987 gives a term-by-term introduction to the terminology of the various sacrifices, while Brichto 1976 and Dahm 
2003 offer different understandings of the historical developments of the various sacrifices in ancient Israel as reflected in the biblical texts. Crüsemann 1985 is especially helpful for comparison with other cultures and the connections among sacrifices, tribute or taxes, and political institutions.

Anderson, Gary A. Sacrifices and Offerings in Ancient Israel: Studies in Their Social and Political Importance. Harvard Semitic Monographs 41. Atlanta: Scholars Press, 1987.

Basic investigation of terminology of sacrifice, in a methodical and thorough manner. Good starting point on which to build.

Brichto, Herbert C. "On Slaughter and Sacrifice, Blood and Atonement." Hebrew Union College Annual 58 (1976): 19-55.

Detailed argument including discussion of Hebrew terms for sacrifice, and the attitudes throughout ancient Israel toward meat consumption, based on the differences among 1 Samuel 14, Deuteronomy, and Leviticus.

Crüsemann, Frank. "Der Zehnte in der israelitischen Königszeit.” Wort und Dienst 18 (1985): 21-47.

Sets the various tithe texts of the Old Testament/Hebrew Bible in conversation with the history of ancient Israel and with ancient Near Eastern taxes and tithes to the various empires of the Iron Age. Helpful attempt to bring together various kinds of data to construct a view of the meanings of texts in their historical settings. In German.

Dahm, Ulrike. Opferkult und Priestertum in Alt-Israel: Ein kultur- und religionswissenschaftlicher Beitrag. Beihefte zur Zeitschrift für die alttestamentliche Wissenschaft 327. Berlin: de Gruyter, 2003.

Detailed German discussion. Methodical treatment of sacrifice's development in the Old Testament texts and their historical period.

\section{Feasts}

Many of the festive meals depicted in the Old Testament/Hebrew Bible take place as part of the three-part festival cycle. Passover and its relationship with the other spring festival (Unleavened Bread) especially have elicited scholarly debate. Texts may be interpreted in light of cultural comparisons (Blum and Lux 2006), ritual theory (Prosic 2004), and Old Testament narratives (Willi-Plein 1993). These treatments often overlap with those on Sacrifices and Offerings, though they also raise more issues with regard to historical development of the feasts. Altmann 2010 and Braulik's two 1994 essays (Braulik 1994a, Braulik 1994b) also highlight the anthropological concerns. Volgger 2002 helps with a straightforward comparison of the various appearances of the festivals in the Pentateuchal books. 
Altmann, Peter F. "Deuteronomy's Festive Meals: The Interplay of Politics and Religion in Their Ancient Near Eastern Context." PhD diss., Princeton Theological Seminary, Princeton, NJ, 2010.

Brings together various methodologies (anthropology, ritual studies, ancient Near Eastern comparisons, iconography) for interpreting festive meals.

Blum, Erhard, and Rüdiger Lux, eds. Festtraditionen in Israel und im Alten Orient. Veröffentlichungen der Wissenschaftlichen Gesellschaft für Theologie 28. Gütersloh, Germany: Gütersloher Verlagshaus, 2006.

Contains essays of varying quality, in German, addressing feasts from Israel, Ugarit, Mesopotamia, and Egypt. Helpful for specific questions and for providing an overview of Continental European scholarly approaches, but little overall perspective is provided.

Braulik, Georg. "Commemoration of Passion and Feast of Joy: Popular Liturgy According to the Festival Calendar of the Book of Deuteronomy (Deut 16:1-17)." In The Theology of Deuteronomy: Collected Essays of Georg Braulik. O.S.B. Translated by U. Lindblad, 67-85. North Richland Hills, TX: BIBAL Press, 1994a.

Translation of "Leidensgedächtnisfeier und Freudenfest: 'Volksliturgie' nach dem deuteronomischen Festkalender (Dtn 16, 1-17)," published in Studien zur Theologie des Deuteronomiums. (Stuttgart: Verlag Katholisches Bibelwerk, 1988), pp. 95-122. Detailed investigation of the passage, its theology, its literary history, and its sociology.

Braulik, Georg. "The Joy of the Feast: The Conception of the Cult in Deuteronomy." In The Theology of Deuteronomy: Collected Essays of Georg Braulik. O.S.B. Translated by U. Lindblad, 27-65. North Richland Hills, TX: BIBAL Press, 1994b.

Translation of "Die Freude des Festes: Das Kultverständnis des Deuteronomium-die älteste biblische Festtheorie," published in Studien zur Theologie des Deuteronomiums (Stuttgart: Verlag Katholisches Bibelwerk, 1988), pp. 161-218. Focuses primarily on the theology and anthropology in the passage.

Prosic, Tamara. The Development and Symbolism of Passover until 70 CE. Journal for the Study of the Old Testament Supplement 414. London: T\&T Clark, 2004.

Reads the Passover texts in light of van Gannep's "rite of passage" ritual theory. Synchronic focus.

Volgger, David. Israel wird feiern: Untersuchung zu den Gesetztexten in Exodus bis Deuteronomium. Arbeiten zu Text und Sprache im alten Testament 73. St. Ottilien, Germany: EOS, 2002. 
In German. Systematic and thorough reading of the festival calendars.

Willi-Plein, Ina. Opfer und Kult im alttestamentlichen Israel: Textbefragungen und Zwischenergebnisse. Stuttgarter Bibelstudien 153. Stuttgart: Katholische Bibelwerk, 1993.

Sets the biblical texts in the wider religious-historical context. Good German overview to sacrifices and sanctuaries in ancient Israel.

\section{Eating and Drinking in Narrative Texts}

MacDonald 2008 remains the broadest and most theoretically informed starting point. Sharon 2002 offers a very different approach and is attuned to the overarching literary structures of texts with motifs of eating and drinking. Hamilton 2009 and Klingbeil 2006 explore the role that meals play in the politics of the Hebrew Bible/Old Testament and can be read profitably with the Royal Texts of the ancient Near East. Janzen 2004 highlights how the same sacrificial or festal motifs can be used by authors for various rhetorical purposes.

Hamilton, Mark. W. "At Whose Table? Stories of Elites and Social Climbers in 1-2 Samuel.” Vetus Testamentum 59 (2009): 513-532.

Investigates the role of "the table" in ancient Israelite politics, as displayed in the stories of Nabal and Barzillai.

Janzen, David. The Social Meanings of Sacrifice in the Hebrew Bible: A Study of Four Writings. Beihefte zur Zeitschrift für die alttestamentliche Wissenschaft 344. Berlin: de Gruyter, 2004.

Good, clear structure, and very helpful methodology section, even if one is not interested in the same texts that he analyzes.

Klingbeil, Gerald A. “'Momentaufnahmen' of Israelite Religion: The Importance of the Communal Meal in Narrative Texts in I/II Regum and Their Ritual Dimension." Zeitschrift für die alttestamentliche Wissenschaft 118 (2006): 22-45.

Investigates instances of eating and drinking in 1-2 Kings and their possible relationships with larger ritual events. Helpful for an introduction to the larger symbolic meanings related to meals in the Old Testament and how they have generally been overlooked.

MacDonald, Nathan. Not Bread Alone: The Uses of Food in the Old Testament. Oxford: Oxford University Press, 2008. 
To date, the best book-length overview of meals and food in the Old Testament. Incorporates narrative analysis, theoretical reflection on anthropological and sociological concerns, and dietary concerns. Directly addresses Deuteronomy, Judges, Samuel-Kings, and Early Second Temple texts (e.g., Judith), among others. Shows how attention to food in the texts leads to rich interpretations.

Sharon, Diane M. Patterns of Destiny: Narrative Structures of Foundation and Doom in the Hebrew Bible. Winona Lake, IN: Eisenbrauns, 2002.

Uses structuralism to analyze various narratives in which eating and drink play important rules.

\section{Latter Prophets and Writings}

There remain many holes in the scholarship of these texts with regard to food. Nonetheless, Brenner 1999 shows methodological possibilities for other texts; Greer 2007 relates archaeology and text. Hagelia 2003 gives a good overview of possible important ancient Near Eastern and biblical comparisons before turning to Isaiah.

Brenner, Athalya. "The Food of Love: Gendered Food and Food Imagery in the Song of Songs." Semeia 86 (1999): 101-112.

Philological analysis of the language of food and drink, concluding that while the female voice is dominant in the poems, the woman is more often portrayed as the food, and the man more often as the consumer.

Greer, Jonathan S. "A Marzeah and a Mizraq: A Prophet's Mêlée with Religious Diversity in Amos 6.4-7." Journal for the Study of the Old Testament 32 (2007): 243262.

Displays recent scholarly methodology for interpreting meal texts. Also important for bringing together food studies and the long-debated practice of the marzeach festive meal.

Hagelia, Hallvard. "Meal on Mount Zion: Does Isa 25:6-8 Describe a Covenant Meal?" Svensk Exegetisk Årsbok 68 (2003): 73-96.

Introduces a number of the basic questions that arise when considering what makes a meal a "covenant" or "eschatological" meal. Helpful in its placing of this meal text in its ancient Near Eastern and biblical contexts.

McLaughlin, John L. The Marzeah in Prophetic Literature: References and Allusions in Light of the Extra-Biblical Evidence. Vetus Testamentum Supplement 86. Leiden, The Netherlands: E. J. Brill, 2001. 
Investigates the marzeah in its manifestations from pre-biblical Ebla and Ugarit to the post-Hebrew Bible West Semitic (Phoenician, Nabatean, Palmyrian) appearances, in order to interpret the meaning of the prophetic texts that possibly include the celebration (Amos, Hosea, Isaiah, Jeremiah, Ezekiel). Thorough, detailed study. Remains within the confines of Hebrew Bible and ancient Near Eastern studies.

\section{Food and Gender}

Gender issues play key roles in questions of food preparation and presentation throughout history and across cultures. McKinlay 1996 addresses the question of women hosts in the Old and New Testaments. Meyers 1988 is concerned with the question of gender egalitarianism on the ground in early Israel, while Braulik 2001 addresses only Deuteronomy's vision of sacrifice. Claassens 2004 is most helpful for considerations of the divine role in food production and provision as it relates to portrayals of women.

Braulik, Georg. "Durften auch Frauen in Israel opfern? Beobachtungen zur Sinn- und Festgestalt des Opfers im Deuteronomium." In Studien zum Deuteronomium und seiner Nachgeschichte, 59-89. By Braulik, Georg. Stuttgarter biblische Aufsatzbände 33. Stuttgart: Verlag Katholisches Bibelwerk, 2001.

Suggestively posits that because the wife is not mentioned as part of the offeror's companions in Deuteronomy 12,14, and 16, she was conceived of as part of the addressees who could carry out the sacrifice.

Claassens, L. Julia M. The God Who Provides: Biblical Images of Divine Nourishment. Nashville: Abingdon, 2004.

Considers images of God in the role of motherly provider of food for Israel.

McKinlay, Judith E. Gendering Wisdom the Host: Biblical Invitations to Eat and Drink. Journal for the Study of the Old Testament Supplement 216. Gender, Culture, Theory 4. Sheffield, UK: Sheffield Academic Press, 1996.

Pinpoints questions of gender involved in meal settings. Interested in broader questions of gender and theology growing from Proverbs, Ben Sira, and John 4.

Meyers, Carol. Discovering Eve: Ancient Israelite Women in Context. New York: Oxford University Press, 1988.

Integrates archaeological evidence and Hebrew Bible texts to portray the experience of women in Iron Age I Israel (the period of the United Monarchy). Many important data on food preparation.

\section{Second Temple Judaism}


Food and meal practices in Second Temple Judaism (the end of the Old Testament/Hebrew Bible period, the "Intertestamental period," and the time of Jesus) experienced a diversity of approaches to dietary laws and commensal understandings. The importance of food and meals for identification with a sect or minority group is seen in Baumgarten 1998 and Goodman 1990. On intertestamental literature, see MacDonald 2006 and Kieweler 1998. For diverging views on Passover and its relationship to wider Greco-Roman meals, see Bokser 1984 and Stein 1966. For rabbinic Judaism in the Roman Empire, see Rosenblum 2010 in addition to Bokser 1984.

Baumgarten, Albert I. "Finding Oneself in a Sectarian Context: A Sectarian's Food and Its Implications." In Self, Soul and Body in Religious Experience. Edited by Albert I. Baumgarten with Jan Assmann and Guy G. Stroumsa, 125-147. Leiden, The Netherlands: E. J. Brill, 1998.

Helpful overview of the way various Jewish sects (including John the Baptist) used food choices as a way to mark identity.

Bokser, Baruch. The Origins of the Passover Seder: The Passover Rite and Early Rabbinic Judaism. Berkeley: University of California Press, 1984.

Clear presentation of the pre-70 ce texts relating to the Passover. Focuses especially on the Mishnah, however. Disputes Stein 1966.

Goodman, Martin. "Kosher Olive Oil in Antiquity." In A Tribute to Géza Vermés: Essays on Jewish and Christian Literature and History. Edited by P. R. Davies and R. T. White, 227-245. Journal for the Study of the Old Testament Supplement 100. Sheffield, UK:

Sheffield Academic Press, 1990.

Clear description of the discussion surrounding the use of non-Jewish-produced oil by Jews in the Hellenistic period.

Kieweler, Hans-Volker. "Benehmne bei Tisch." Der Einzelne und seine Gemeinschaft bei Ben Sira. Edited by R. Egger-Wenzel and I. Krammer, 191-215. Beihefte zur Zeitschrift für die alttestamentliche Wissenschaft 270. Berlin: de Gruyter, 1998.

Investigates Hebrew, Syriac, and Greek texts of table sayings in detail. Shows that the Greek text of Ben Sira, while excellent Greek, is in fact very conversant with Hebrew Bible texts, and the advice in the book is influenced greatly by the Hebrew Bible texts, though set in the culture and era of Hellenism and its customs.

Löhr, Hermut. "Speisenfrage und Tora im Judentum des Zweiten Tempels und im entstehenden Christentum." Zeitschrift für die neutestamentliche Wissenschaft und die Kunde der älteren Kirche 94 (2003): 17-37. 
Lays out the difference between the concerns about food laws found in early Jewish versus early Christian (New Testament) texts.

MacDonald, Nathan. "Food and Drink in Tobit and Other 'Diaspora Novellas."' In Studies in the Book of Tobit. Edited by Mark Bredin, 165-178. Library of Second Temple Studies 55. London: T\&T Clark, 2006.

Good introduction to the range of food issues that developed out of the earlier periods into the Hellenistic world. Attention to Tobit, Judith, Daniel, and Esther.

Rosenblum, Jordan. Food and Identity in Early Rabbinic Judaism. Cambridge, UK: Cambridge University Press, 2010.

Best overview of the issues of dietary and other food choices that affected ethnic and gender identity in the 3rd century ce.

Stein, Siegfried. "The Influence of Symposium Literature on the Literary Form of the Pesah Haggadah." Journal of Jewish Studies (1966): 13-44.

Reprinted in Henry A. Fischel, ed., Essays in Greco-Roman and Related Talmudic Literature (New York: KTAV, 1976). Argues for the fundamental influence of the Hellenistic symposium on the formation of the Jewish Passover Seder as it is known today. This thesis has been accepted by a large number of recent New Testament studies.

\section{Qumran}

The texts of the Dead Sea Scrolls and their related archaeological setting have provided new understandings of the New Testament literature in many areas, including the importance of food choices for community identity. Kuhn 1957 and Schiffman 1979 lay bare the early interpretations of the data. Magness 2004 is the work of a mature scholar, giving an overview of the development of scholarly thought, while Davies 1999 shows how various methodologies can also be applied to the meals and their implications for the definition of identity in the Qumran community and its texts. Other treatments of the Qumran material may be found in the monographs in the New Testament section of this bibliography.

Davies, Philip R. "Food, Drink, and Sects: The Question of Ingestion in the Qumran Texts." Semeia 86 (1999): 151-163.

Analyzes the Rule of the Community (1QS) and the Damascus Document scrolls from Qumran with Mary Douglas's theoretical perspective that body orifices define identity boundaries. For 1QS even more than the Damascus Document, communal meals were even more limited to members of the sect, in order to protect community purity. 
Kuhn, Karl Georg. "The Lord's Supper and the Communal Meal at Qumran." In The Scrolls and the New Testament. Edited by Krister Stendahl, 65-93. London: SCM Press, 1957.

Revised and translated from "Über den ursprünglichen Sinn des Abendmahles und sein Verhältnis zu den Gemeinschaftsmahlen der Sektenschrift," Evangelische Theologie 10 (1950-1951): 508-527. The article highlights the changes in understanding the development of the Eucharist from the earlier work of Bultmann and Jeremias that came about in light of the discovery of the Qumran texts.

Magness, Jodi. "Communal Meals and Sacred Space at Qumran." In Debating Qumran: Collected Essays on Its Archaeology. Edited by Jodi Magness, 81-112. Leuven, Belgium: Peeters, 2004.

Originally appeared in Shaping Community: The Art and Archaeology of Monasticism; edited by S. McNally (Oxford: Archaeopress, 2001), pp. 15-28. Readable overview of textual and archaeological data; good interaction with earlier scholarship.

Schiffman, Lawrence H. "Communal Meals at Qumran.” Revue de Quman 10/1 (1979): 45-56.

Early analysis of the meals; thus, in places, outdated by more recent data, yet sets many of the terms of the debate over the cultic and messianic nature of the meals.

\section{Greco-Roman Context}

Entrée into the New Testament texts can be provided both by the earlier Jewish and ancient Israelite traditions and by the contemporary Greco-Roman milieu. With regard to the latter, of primary importance is the rise of the Hellenistic symposium. Subtle changes in food production also took place within the Roman world. In this section, Food Supply and Distribution, Diet, Food in Religion and Society, and Symposium are covered.

\section{Food Supply and Distribution}

These studies provide material and economic context for the provision of the Greek and Roman empires at large, thus setting the stage for the specific issues arising in the New Testament texts. Alston and van Nijf 2008 and Garnsey 1983 provide oversight on the interplay between governmental and private donations for meeting nutritional needs, with Alston and van Nijf 2008 giving up-to-date engagements viewing various periods and international trade. Frayn 1993, because it is more regional, is helpful for microinteractions on a local scale. Rickman 1980 narrows in on the particular problem for the metropolis of Rome. 
Alston, Richard, and Onno van Nijf, eds. Feeding the Ancient Greek City. GroningenRoyal Holloway Studies on the Greek City after the Classical Age. Vol. 1. Leuven, Belgium: Peeters, 2008.

Collection of up-to-date discussions of postclassical Greece and the Greco-Roman world (including Egypt and west Asia). Mostly addresses various taxes on production and the public versus private roles in alleviating grain shortages.

Frayn, Joan M. Markets and Fairs in Roman Italy: Their Social and Economic Importance from the Second Century BC to the Third Century AD. Oxford: Clarendon, 1993.

Readable overview of the various types of markets that existed, which might also be extrapolated for the Roman Empire as a whole. More focused on the local exchange of goods, rather than on long-distance trade.

Garnsey, Peter. "Grain in Rome.” In Trade in the Ancient Economy. Edited by C. R. Whittaker, Peter Garnsey, and Keith Hopkins, 118-130. Berkeley: University of California Press, 1983.

Investigates the sources and distribution of grain for Rome's near one million inhabitants during the 1 st century bce to the 3rd century ce. Interacts critically with ancient literary sources. Helpful for understanding the development of Rome from a republic to an empire, and the interplay between state and private distribution.

Rickman, George. The Corn Supply of Ancient Rome. New York: Oxford University Press, 1980.

This work approaches more the issue of supply rather than distribution, especially the transportation and storage of grain. Insightful on the increasing role of the Roman state involvement in this sphere of life.

\section{Diet}

Broshi 2001 and Dar 1995 give clear introductions. Garnsey 1988 is especially good for economic and political factors, while Beer 2009 and Wilkins and Hill 2006 provide excellent, more thorough studies. André 1961 has provided the basis for current scholarly discussion.

André, Jacques. L'alimentation et la cuisine à Rome. Études et Commentaires 38. Paris: Klincksieck, 1961.

Foundational and systematic overview of the primary foodstuffs: legumes, grains, fruits, meat, fish, and drinks. Also discusses taste in relation to cooking 
techniques, sauces, and spices. Covers more than one thousand years and works primarily from textual evidence.

Beer, Michael. Taste or Taboo: Dietary Choices in Antiquity. Totnes, UK: Prospect Books, 2009.

Detailed discussion of the foodstuffs available and how consumption was determined by necessity and choice. Thorough and up to date.

Broshi, Magen. "The Diet of Palestine in the Roman Period: Introductory Notes." In Bread, Wine, Walls and Scrolls. Edited by M. Broschi, 121-143. Journal for the Study of the Pseudopigrapha Supplement 36. Sheffield, UK: Sheffield Academic Press, 2001.

Overview of available foods. Mostly from Talumudic sources. First published in The Israel Museum Journal 5 (1986): 41-56.

Dar, Shimon. "Food and Archaeology in Romano-Byzantine Palestine." In Food in Antiquity. Edited by John Wilkens, David Harvey, and Mike Dobson, 326-336. Exeter, UK: University of Exeter Press, 1995.

Clear, short introduction, with a good bibliography.

Garnsey, Peter. Famine and Food Supply in the Graeco-Roman World: Responses to Risk and Crisis. Cambridge, UK: Cambridge University Press, 1988.

Considers the topic for the 6th century bce to the 3rd century ce, addressing the differences in urban versus rural settings. One of the groundbreaking works on social history of food in Antiquity, investigating kin and political responses to famine, with special attention on Athens and Rome.

Wilkins, John M., and Shaun Hill. Food in the Ancient World. Ancient Cultures. Malden, MA: Blackwell, 2006.

Gives broad background (beginning in the 8th century bce) and the wide GrecoRoman world. Later authors Galen and Athenaeus feature prominently.

\section{Food in Religion and Society}

Titles in this section consider distinctly social and religious aspects of consumption and distribution. No doubt there is also much overlap with Food Supply and Distribution and with the literature on the Symposium. Evans 1981 highlights hunger and food as a decisive motive in political and military policy. Nielsen and Nielsen 1998 draws a step closer to specific questions of the early Christian and Jewish communities. Detienne and Vernant 1989 is the preeminent anthropological work on classical Greek sacrifice. Sokolowski 1969 provides primary texts for Greek sacrifices. 
Detienne, Marcel, and Jean-Pierre Vernant. The Cuisine of Sacrifice of the Greeks.

Translated by Paula Wissing. Chicago: University of Chicago Press, 1989.

Translation of La cuisine du sacrifice en pays grec (Paris: Gallimard, 1979).

Contains a number of studies on sacrifice and table both in Greek practice and in literary sources (Hesiod). Very detailed bibliography included.

Evans, John K. "Wheat Production and Its Social Consequences in the Roman World." Classical Quarterly 31 (1981): 428-442.

Notes that the importance of provisioning armies in the Roman world was related to success as well as other measures of support (for children) by the empire, related to political policy. Shows the imminent and ever-reccurring danger of starvation.

Nielsen, Hanne Sigismund, and Inge Nielsen, eds. Meals in a Social Context: Aspects of the Communal Meal in the Hellenistic and Roman World. Aarhus Studies in Mediterranean Antiquity 1. Aarhus, Denmark: Aarhus University Press, 1998.

Varied collection of articles addressing specific topics in Greco-Roman backgrounds, Qumran and Jewish communities, and 1 Corinthians.

Sokolowski, Franciszek. Lois sacrées des cités grecques. École française d'Athènes: Travaux et mémoires des anciens membres étrangers de l'école et de divers savants. Paris: E. de Boccard, 1969.

Contains the epigraphic texts (in Greek) on sacrifice from the Greek heartland. Also given are the related publications of the individual texts as of the date of the publication.

\section{Symposium}

The symposium, a meal tradition that grew to become the staple meal event of GrecoRoman culture, arguably forms the background of many New Testament meal depictions and instructions. Dentzer 1982 is a magnum opus of historical reconstruction. Roller 2006 and Slater 1991 elucidate the social code and implications of dining. Gowers 1993 considers how literature takes up and uses food and meal elements rhetorically.

Dentzer, Jean-Marie. Le motif du banquet couché dans le Proche-Orient et le monde grec du VIIe au IVe siècle avant J.-C. Bibliothèque des Écoles Françaises d'Athènes et de Rome, fasc. 246. Rome: Écoles Françaises de Rome, 1982.

Most important and detailed work on the development of the banquet motif from its ancient Near Eastern origins into its Hellenistic form. Provides many photographs and drawings of iconographic depictions. 
Gowers, Emily. The Loaded Table: Representations of Food in Roman Literature. New York: Oxford University Press, 1993.

Example of close literary readings of Roman satires and poems. Assumes extensive knowledge of Roman culture and literature.

Roller, Matthew B. Dining Posture in Ancient Rome: Bodies, Values, and Status. Princeton, NJ: Princeton University Press, 2006.

Detailed description of social relations at meals, focusing especially on gender and children. Contains a number of illustrations.

Slater, William J., ed. Dining in a Classical Context. Ann Arbor: University of Michigan Press, 1991.

Essential introduction on the practical issues surrounding the symposium. Made up of diverse essays. One essay, Walter Burkert's "Oriental Symposia," gives an overview of the cultural exchange and comparisons of banquets between Greece and the ancient Near East.

\section{New Testament}

The New Testament texts incorporate food, drink, and meal motifs for many purposes. Classic biblical scholarship has focused primarily on the theological meaning of The Last Supper and the Lord's Supper, while newer works have tended to take their cue from Feeley-Harnik 1981, which turned to anthropology. Smith 2003, Klinghardt 1996, and Taussig 2009 are three fundamental works that use ritual studies and sociology to turn the focus away from the theological words in the biblical texts to the practice of the early churches, especially in light of the wider Greco-Roman tradition. Chilton 1994 offers something of a critique of these works in its return to the Jewishness of the earliest Christian meals. Nielsen and Nielsen 1998 (cited under Food in Religion and Society) offers a more eclectic group of perspectives and for this reason is a good contrast to Smith 2003 and other studies, whose perspectives are also represented quite strongly at the website Meals in the Greco-Roman World, which offers very up-to-date information.

Chilton, Bruce. A Feast of Meanings: Eucharistic Theologies from Jesus through Johannine Circles. Novum Testamentum Supplement 72. Leiden, The Netherlands: E. J. Brill, 1994.

Interprets New Testament meals and Eucharistic portrayals developing from Jewish purity and sacrificial setting during the life of Jesus into diverse early Christian communities displaying various Passover and non-Passover HellenisticRoman concerns. Contrast with Smith 2003 and Taussig 2009, which emphasize the Jewish concerns about Jesus and early Christianity's meals. 
Feeley-Harnik, Gillian. The Lord's Table: The Meaning of Food in Early Judaism and Christianity. Washington DC: Smithsonian Institution Press, 1981.

One of the first attempts to understand the meals in the New Testament through a sociological lens.

Klinghardt, Matthias. Gemeinschaftsmahl und Mahlgemeinschaft: Soziologie und Liturgie frühchristlicher Mahlfeiern. Texte und Arbeiten zum neutestamentlichen Zeitalter 13. Tübingen, Germany: Franke, 1996.

Tour de force, detailed discussion of the Hellenistic-Roman symposium backgrounds for early Christian meals. Groundbreaking work that shares similar conclusions with Smith 2003.

Meals in the Greco-Roman World: A Seminar of the Society of Biblical Literature.

Great website containing recent papers. Best source for latest scholarship. Full articles available online.

Smith, Dennis E. From Symposium to Eucharist: The Banquet in the Early Christian World. Minneapolis: Fortress, 2003.

Investigates classical Hellenistic-Roman banquets and concludes that the symposium was one basic dining custom across the various cultures, which undergirded Jewish and early Christian meal practices. Provides a wealth of detailed analysis of Greco-Roman meals, but treatments of New Testament texts can be one sided. Essential source for summary of Greco-Roman banquets.

Taussig, Hal. In the Beginning Was the Meal: Social Experimentation and Early Christian Identity. Minneapolis: Fortress, 2009.

Assumes Greco-Roman symposium as the basic form for early Christian meals. Argues these meals were the primary location for experimentation and development of early Christian identity. Good introduction to sociological and ritual studies and reflections on Christian origins in meals, but often assumes conclusions and is one sided in use of secondary literature.

\section{The Last Supper and the Lord's Supper}

The origins of Jesus's Last Supper and the so-called Lord's Supper of 1 Corinthians 11 have formed the backbone of discussion on early Christian meals for centuries. Jeremias 1966 is the detailed work of a leading scholar of a past generation. Theissen 2007 provides a more recent appraisal of the discussion, especially in German-speaking literature. Whether the Last Supper was a Passover or not is addressed in BrumbergKraus 1999 and Klawans 2001. The continued reflex of this debate in the post-biblical 
era is seen in Wilson 1985. The additional studies in the following New Testament subsections provide additional resources.

Brumberg-Kraus, Jonathan D. “"Not by Bread Alone ...': The Ritualization of Food and Table Talk in the Passover Seder and in the Last Supper." Semeia 86 (1999): 165-191.

Clear, in-depth comparison of the similarities and differences between the foundational Jewish and Christian meals and their messages in Antiquity. Brings together a wide range of issues including ritual theory and the Hellenistic symposium.

Jeremias, Joachim. The Eucharistic Words of Jesus. New York: Scribner, 1966.

Translated by Norman Perrin from the German, Die Abendmahlsworte Jesu, 3d ed. (Göttingen, Germany: Vandenhoeck \& Ruprecht, 1960). Classic comprehensive treatment of the New Testament texts. Important basis for understanding subsequent debate.

Klawans, Jonathan. “Was Jesus’ Last Supper a Seder?” Bible Review 17.5 (2001): 24-33, 47.

Popular summary with illustrations from modern and ancient Passover celebrations of the development of the debate for and more recently against the identification of the Last Supper of the historical Jesus with the Passover Seder.

Theissen, Gerd. "Sakralmahl und sakramentales Geschehen: Abstufungen in der Ritualdynamik des Abendmahls." In Herrenmahl und Gruppenidentität. Edited by Martin Ebner, 166-186. Quaestiones Disputatae 221. Freiburg im Bresigau, Germany: Herder, 2007.

Provides helpful German overview of basic elements of ritual and of classical German-language Eucharist interpretation since Lietzmann (1926), arguing for two types of meals (agape and Eucharist) within the same communities.

Wilson, Stephen G. "Passover, Easter, and the Anti-Judaism: Melito of Sardis and Others." In To See Ourselves as Others See Us: Christians, Jews, “Others" in Late Antiquity. Edited by Jacob Neusner and Ernest S. Frerichs, 337-355. Chico, CA: Scholars Press, 1985.

Relates Melito's sermon and the debate over the day of Easter to wider JewishChristian questions of his time. Good insight into how "current events" interact with concerns surrounding traditional sacred banquets.

\section{Synoptic Gospels}


The Gospels of Matthew, Mark, and Luke make wide use of agricultural and meal motifs. Berger 1993 is especially helpful for food production imagery, while Braun 1995 provides a detailed argument for how the Gospel of Luke uses the symposium motif in a highly complex manner. Corley 1993 investigates the frequent appearance of women at Jesus's meals. Heil 1999 is helpful when addressing any text of the Luke-Acts corpus. Smit 2008 narrows in on one key theme in eschatological feasts. Kelhoffer 2005 highlights an insightful methodological shift by including material from the textual prehistory to its reception history.

Berger, Klaus. Manna, Mehl und Sauerteig: Korn und Brot im Alltag der frühen Christen. Stuttgart: Quell-Verlag, 1993.

Detailed development of the agricultural process and use of this imagery in Antiquity and throughout the New Testament texts, but most detailed on the canonical gospels. In German. Can be used for treatments of individual texts through detailed index.

Braun, Willi. Feasting and Social Rhetoric in Luke 14. Society for New Testament Studies Monograph 85. Cambridge, UK: Cambridge University Press, 1995.

Applies Greco-Roman symposium motifs to Jesus's meal with a Pharisee. Very detailed treatment.

Corley, Kathleen E. Private Women, Public Meals: Social Conflict in the Synoptic Tradition. Peabody, MA: Hendrickson, 1993.

Only monograph-length treatment on gender in New Testament meal texts. Views each of the synoptic gospels as going different ways with the received GrecoRoman traditions that at the time became more egalitarian before retreating to more conservative gender roles.

Heil, John Paul. The Meal Scenes in Luke-Acts: An Audience-Oriented Approach. Society of Biblical Literature Monograph 52. Atlanta: Society of Biblical Literature, 1999.

Detailed, scene-by-scene discussion of each meal. Best for studies of specific pericopes in Luke-Acts.

Kelhoffer, James A. The Diet of John the Baptist: "Locusts and Wild Honey" in Synoptic and Patristic Interpretation. Wissenschaftliche Untersuchungen zum Neuen Testament 176. Tübingen, Germany: Mohr Siebeck, 2005.

Investigates the wider cultural context for a diet of locusts and honey and considers the development of John's diet in ascetic traditions and broader patristic and later interpretation. Excellent example of discussion that addresses a question from form-critical through to reception-historical perspectives. 
Smit, Peter-Ben. Fellowship and Food in the Kingdom. Wissenschaftliche

Untersuchungen zum Neuen Testament 234. Tübingen, Germany: Mohr Siebeck, 2008.

Most recent monograph on images of eschatological feasts in the Gospels and Revelation. Traces the appearance of the meals in their individual contexts. Posits that the texts used a number of traditions and have various goals in mind for the use and theological thrust of the banquets.

\section{Johannine Literature}

The Gospel of John's lack of a Last Supper has given rise to a discussion concerning John's lack of sacramentalism (see Bornkamm 1956 and Dunn 1971). Much of this discussion turns on how one understands John 6, which may be interpreted to contain Eucharistic overtones, but also how one understands John 13 (Ball 1985). Further subjects of discussion in the Johannine literature are the possibly metaphorical meanings of eating and drinking (Webster 2003), and the overall structuring of the Gospel according to Jewish feasts (Flebbe 2009). Hodges 1999 and Maritz and van Belle 2006 highlight the metaphorical use of food, drink, and consumption. Daise 2007 provides deep interaction with Jewish sources.

Ball, R. M. "Saint John and the Institution of the Eucharist." Journal for the Study of the New Testament 23 (1985): 59-68.

Argument for a veiled Passover reference in John 13:1. Useful for interaction with early Church Fathers' readings of the passage.

Bornkamm, Günther. "Die eucharistische Rede im Johannes-Evangelium." Zeitschrift für die neutestamentliche Wissenschaft und die Kunde der älteren Kirche 47 (1956): 161169.

In German, a redaction-critical argument helpful both for its methodology and for the questions it raises against the originality of the Eucharistic interpretation of John 6:48ff.

Daise, Michael A. Feasts in John: Jewish Festivals and Jesus' "Hour" in the Fourth Gospel. Wissenschaftliche Untersuchungen zum Neuen Testament II/229. Tübingen, Germany: Mohr Siebeck, 2007.

Argues that the Jewish festal calendar structured an earlier form of the Gospel, and thus for an author deeply knowledgeable about Judaism. Very readable and detailed description of feasts in their literary context.

Dunn, James D. G. “John 6: A Eucharistic Discourse?” New Testament Studies 17 (1971): 328-338. 
Classic defense of the originality of the Eucharistic language in John 6 (contra Bornkamm 1956), but only for use in a negative manner. Good, thorough discussion providing an introduction to the issues involved in the interpretation of this section.

Flebbe, Jochen. "Feasts in John." In Feasts and Festivals. Edited by Christopher Tuckett, 107-124. Contributions to Biblical Exegesis and Theology. Leuven, Belgium: Peeters, 2009.

Shows the significance of Jewish feasts for the structuring of the Gospel as a whole, at least at one early stage. Helpful for diachronic considerations and relationship of feasts to the structure of the book as a whole.

Hodges, Jeffery Horace. “'Ethical' Dualism of Food in the Gospel of John.” Paper presented at the Annual Meeting of the Society of Biblical Literature, Boston, 1999.

Shows how motifs of eating and food can play an important role in the Gospel's theological message. Detailed but short scholarly article.

Maritz, P., and G. van Belle. "The Imagery of Eating and Drinking in John 6:35." In Imagery in the Gospel of John: Terms, Forms, Themes and Theology of Johannine Figurative Language. Edited by Jörg Frey, Jan G. van der Watt, and Ruben Zimmermann, 333-352. Wissenschaftliche Untersuchungen zum Neuen Testament 200. Tübingen, Germany: Mohr Siebeck, 2006.

Sets the metaphors of eating bread and drinking water in John in conversation with Old Testament, intertestamental wisdom, and synoptic gospel traditions. Complex argument, yet broader context helpful for this text and other Johannine texts.

Webster, Jane. Ingesting Jesus: Eating and Drinking in the Gospel of John. Atlanta: Society of Biblical Literature, 2003.

Helpful investigations of the depictions of eating and drinking and related semantic domains in the Gospel of John within their literary world. Concludes that ingesting is a primary category for the Gospel's depiction of following Jesus. Also concludes that John 6 refers to the Eucharist, making ingesting an apropos motif for soteriology in the Gospel.

\section{Paul}

Two concerns have been especially important in the literature on Paul's views of food and meals: his view of the Lord's Supper in 1 Corinthians 11 (Theissen 1982, Lampe 1991) and his views of the consumption and purchase of idol meat in 1 Corinthians 8-11 (Fotopoulos 2003, Gooch 1993, Koch 1999, and Newton 1998) and Romans 14 (Shogren 
2000, Smit 2007). These issues are also addressed by many of the book-length newer studies found in other subsections in New Testament.

Fotopoulos, J. Food Offered to Idols in Roman Corinth: A Socio-Rhetorical Reconsideration of 1 Corinthians 8:1-11:1. Wissenschaftliche Untersuchungen zum Neuen Testament 2, 151. Tübingen, Germany: Mohr Siebeck, 2003.

Reads 1 Corinthians 8-11 in light of data about ancient Corinthian temples and temple service, arguing against Gooch 1993 that Paul remains consistent in his condemnation of eating idol food at pagan temples. Offers significant discussion of the Asklepios, Demeter, Kore, Isis and Sarapis, and additional temples.

Gooch, Peter David. Dangerous Food: 1 Corinthians 8-10 in Its Context. Waterloo, Canada: Wilfrid Laurier University Press, 1993.

Argues that Paul is inconsistent in his argument against the Corinthian Christian's consumption of idol meat, and that the Corinthians rejected his argument. Also includes analysis of Corinthian archaeology, though comes to different conclusions than does Fotopoulos 2003.

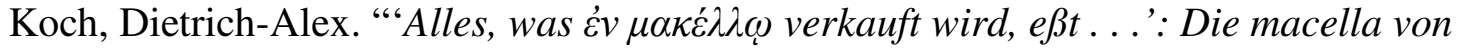
Pompeji, Gerasa und Korinth und ihre Bedeutung für die Auslegung von 1 Kor 10,25." Zeitschrift für die neutestamentliche Wissenschaft und die Kunde der älteren Kirche 90 (1999): 194-219.

Argues (in German) on the basis of newer archaeological studies that there was nonsacrificial meat for sale in the Greco-Roman cities such as Corinth. Includes pictures of the archaeological finds of various markets. Important insights for forming a coherent view of Paul's statements about eating meat in various settings in 1 Corinthians 8-11.

Lampe, Peter. "Das korinthische Herrenmahl im Schnittpunkt hellenistisch-römischer Mahlpraxis und paulinischer Theologia Crucis (1Kor 11,17-34)." Zeitschrift für die neutestamentliche Wissenschaft und die Kunde der älteren Kirche 82 (1991): 183-213.

In-depth discussion in German of Paul's instructions for the communal meal, read in light of the various Greco-Roman symposium traditions. Generally supports D. Smith's (2003) setting of 1 Corinthians 11-14 around a symposium and builds on and critiques Theissen's earlier reconstruction of the issues in 1 Corinthians 11.

Newton, Derek. Deity and Diet: The Dilemma of Sacrificial Food at Corinth. Journal for the Study of the New Testament Supplement 169. Sheffield, UK: Sheffield Academic Press, 1998.

Uses cross-cultural anthropology and historical-critical methodology to argue that Paul's response in 1 Corinthians $8-10$ is coherent, focusing as much on attitudes 
underlying consumption of idol sacrifice as the action itself because of the complexity of understanding toward the consumption of idol sacrifices, thereby prohibiting a more direct unitary solution.

Shogren, Gary Steven. "Is the Kingdom of God about Eating and Drinking or Isn't It? (Romans 14:17).” Novum Testamentum 42 (2000): 238-256.

Good exploration of how food choices (e.g., vegetarianism) flow from understandings of piety.

Smit, Peter-Ben. “A Symposium in Rom 14:17? A Note on Paul's Terminology." Novum Testamentum 49 (2007): 40-53.

Brief, clear display of the similarities between Paul's emphasis on the quality of interpersonal relationships as the most important element of a meal and those of contemporary Greco-Roman culture, suggesting that these values formulate the background for Romans 14:17.

Theissen, Gerd. "The Strong and the Weak in Corinth: A Sociological Analysis of a Theological Quarrel." In The Social Setting of Pauline Christianity. Edited and translated by John H. Schütz, 121-143. Philadelphia: Fortress, 1982.

Translation of "Die Starken und Schwachen in Korinth: Soziologische Analyse eines theologischen Streites," Evangelische Theologie 35 (1975): 155-172. Detailed argument on background for 1 Corinthians 11. Forms the basis of subsequent scholarship.

\section{Acts}

The Book of Acts contains a number of meals, beginning with the idyllic breaking of bread in the upper room in chapters 2 and 4. Gentile-Jewish relationships in the early church are also addressed through the motif of communal eating and dietary laws. Tyson 1983 addresses one such conflict, while Finger 2007 focuses on the broader economic issue of feeding the Jerusalem church.

Finger, Reta Halteman. Of Widows and Meals: Communal Meals in the Book of Acts. Grand Rapids, MI: Eerdmans, 2007.

Readable and in touch with current questions about the sharing of resources versus private property and how these relate to the shared table in Acts 2, 4, and 6.

Tyson, Joseph B. "Acts 6:1-7 and Dietary Regulations in Early Christianity." Perspectives in Religious Studies 10 (1983): 145-161. 
Treats exclusion of widows (whom he understands to be Gentiles) as an instance of Jewish-Gentile dietary law controversy. Underlying argument is that the ideal church according to Acts eats together, so anything that threatens this must be dealt with.

\section{Other Early Christian Texts}

The Deutero-Paulines, Catholic letters, and Revelation, along with post-biblical texts, are important not only for seeing the developments arising from the biblical texts and their communities, but also for positing alternative Christian community practices. The different emphases of the Didache are on display in Betz 1996 and van de Sandt 2002. McGowan 1999 provides the most comprehensive discussion, also of the origins of ascetic approaches to food. Rouwhorst 2006 is more of an overview, and for this reason can be a good entry point. Stein 2008 is one of the few works that looks beyond the Gospels and Paul.

Betz, Johannes. "The Eucharist in the Didache." In The Didache in Modern Research. Edited by Jonathan A. Draper, 244-275. Leiden, The Netherlands: E. J. Brill, 1996.

Translation of "Die Eucharistie in der Didache," Archive für Liturgiewissenschaft 11 (1969): 11-39. Carefully reasoned comparison of the Didache, placing it in the development of the Lord's Supper liturgies of the New Testament.

McGowan, Andrew. Ascetic Eucharists: Food and Drink in Early Christian Ritual Meals. Oxford Early Christian Studies. Oxford: Clarendon, 1999.

Detailed scholarly discussion. Especially helpful for developments of the postNew Testament. Good overview of food stuffs eaten in larger Greco-Roman culture and in the early Christian communities.

Rouwhorst, Gerard. "Table Community in Early Christianity." In A Holy People: Jewish and Christian Perspectives on Religious Communal Identity. Edited by Marcel Poorthuis and Joshua Schwartz, 69-84. Leiden, The Netherlands: E. J. Brill, 2006.

Part of the general shift in scholarship (see also McGowan 1999 and, under New Testament, Smith 2003 and Taussig 2009) that focuses on the ritual and social questions surrounding early Christian meals rather than a singular focus on theological meanings. Short overview.

Stein, Hans Joachim. Frühchristliche Mahlfeiern: Ihre Gestalt und Bedeutung nach der neutestamentlichen Briefliteratur und der Johannesoffenbarung. Wissenschaftliche Untersuchungen zum Neuen Testament 255. Tübingen, Germany: Mohr Siebeck, 2008.

German monograph aware of recent trends in English and German scholarship. Helpful history of scholarship and best recent work on Revelation, the so-called Deutero-Pauline letters, and Jude. 
van de Sandt, Huub. "'Do Not Give What Is Holy to the Dogs' (Did 9:5D and Matt 7:6A): The Eucharistic Food of the Didache in Its Jewish Purity Setting." Vigiliae Christianae 56 (2002): 223-246.

Argues against the reliance of the Didache on Matthew, proposing instead a Jewish sacrificial purity background for the Eucharistic instructions of the Didache. Important for the discussion of early Christian meal settings in relation to Judaism and Greco-Roman culture. 